INFLAMMATORY BOWEL DISEASE

\title{
Induction of experimental ulcerative colitis by Fusobacterium varium isolated from colonic mucosa of patients with ulcerative colitis
}

\author{
T Ohkusa, I Okayasu, T Ogihara, K Morita, M Ogawa, N Sato
}

See end of article for authors' affiliations

.....................

Correspondence to: Dr N Sato, Department of Gastroenterology, Juntendo University, School of Medicine, 2-1-1 Hongo, Bunkyo-ku, Tokyo

113-8421, Japan: nsato@med.juntendo.ac.jp

Accepted for publication 5 July 2000
Background: Bacteria are implicated in certain forms of model chronic colitis but the identity and role of bacteria in human ulcerative colitis (UC) are uncertain.

Aims: To isolate pathogenic bacteria from inflamed mucosa of patients with UC, to examine whether the bacteria have a toxin to Vero cells, and to determine whether the toxin induces UC-like lesions in animals.

Methods: Bacteria were isolated from UC patients and supernatants from cultures were filtered and tested for cytotoxicity to Vero cells. Bacterial cells producing the cytotoxic supernatants were examined by polymerase chain reaction for verotoxin genes. Culture supernatants of cytotoxic strains were examined by high performance liquid chromatography for organic acid concentrations. Mice were given enemas containing organic acid at the mean concentration in the supernatants of cytotoxic strains to ascertain whether colonic lesions appear in UC.

Results: Only supernatants from cultures of Fusobacterium varium killed Vero cells. Bacterial cells lacked verotoxin genes. Bacterial culture supernatants contained high concentrations of $n$-butyric acid and the mean concentration (32 mmol/l) was cytotoxic to Vero cells. Twenty four hours after mice were given enemas containing either butyric acid or $F$ varium culture supernatants, colonic ulcers with crypt abscesses, inflammatory cell infiltration, and apoptotic changes were observed.

Conclusions: Butyric acid in culture supernatants from cultures of $F$ varium caused UC-like lesions in mice. This study indicates that $F$ varium may be one of the elusive pathogenic factors in UC.
$\mathrm{T}$ he aetiology of ulcerative colitis (UC) is unknown. Although UC shares histological features with infectious colitis, ${ }^{1}$ it can be differentially diagnosed from colitis caused by other infectious agents (for example, shigella, haemorrhagic Escherichia coli, salmonella, amoebiasis, gonorrhea, chlamydia, Clostridium difficle) by stool culture, mucosa culture, and serological testing. Normal luminal bacteria are involved in spontaneous colitis which does not develop in germ free knockout mice. ${ }^{2-5}$ The luminal microflora in UC has been examined in many studies. ${ }^{6-9}$ Patients with UC have abnormally large numbers of facultative anaerobic bacteria. ${ }^{6}$ One of these, adhesive $E$ coli, has been implicated in the pathogenesis of UC. ${ }^{7}$ In two studies, E coli cells that produced verotoxin were isolated from the stools of four of 18 patients during UC relapse ${ }^{8}$ and from rectal biopsies of all 28 patients during relapse or remission of UC. ${ }^{9}$ In another study, however, stools from 34 patients with active UC were negative for such bacteria. ${ }^{10}$

However, the mucosal microflora should play a pivotal role because infections start with adherence of microorganism to the host. ${ }^{11}$ We have previously reported that bacteria invading the colonic mucosa were found in the mucosal microflora of all 16 patients with UC but in none of 10 controls. ${ }^{12}$ Recently, Swidsinski et al reported high concentrations of mucosal bacteria in patients with UC but not in healthy controls. ${ }^{13}$ We were able to detect invasive bacteria in mucus and mucosa by an invasion assay ${ }^{14}$ that used imipenem instead of gentamicin. Imipenem was not absorbed into the intestinal mucosa ${ }^{15}$ and killed both aerobic and anaerobic bacteria in the lumen. ${ }^{16}$ Here, we isolated bacteria from the inflamed mucosa and examined whether the species contained verotoxin. The toxin producing species were then tested in experimental animals for their ability to cause lesions resembling those of UC.

\section{METHODS}

\section{Isolation of mucosal bacteria}

Biopsy specimens were obtained with informed consent from the inflamed mucosa of 10 patients (mean age 36 (SD 11) years; seven men and three women). Patients were selected at random from 31 consecutive patients with active UC, diagnosed by endoscopic and pathological findings, and had no prior history of antibiotic use. Mucosal microorganisms were examined bacteriologically as described elsewhere. ${ }^{17}$ In brief, specimens were first incubated with imipenem $(50$ $\mu \mathrm{g} / \mathrm{ml}$ saline) for one hour at $37^{\circ} \mathrm{C}$. Serially diluted samples were spread on four agar plates for aerobic and eight agar plates for anaerobic culture. Isolated bacteria were examined by the disk diffusion test for imipenem sensitivity (minimal inhibitory concentration $<4 \mu \mathrm{g} / \mathrm{ml}$ ).

\section{In vitro toxicity tests}

Culture supernatants ( $\mathrm{pH}$ 6.3-6.6) from all 42 isolates of 20 species were tested for toxicity to Vero cells. ${ }^{18}$ Vero cells were grown in Ham nutrient mixture F12 (Nissui Pharmaceutical Co, Tokyo, Japan) with $10 \%$ fetal calf serum and $50 \mathrm{mg} / \mathrm{ml}$ gentamicin. Vero monolayers were obtained by seeding $10^{4}$ cells in each well 48 hours before use. Bacterial strains were incubated in ABCM broth (Eiken Chemicals, Tokyo, Japan) at $37^{\circ} \mathrm{C}$ for 72 hours. The density of cultured bacteria was estimated by counting the number of colonies per millilitre. Culture supernatant $(25 \mu \mathrm{l})$ was added to each $100 \mu \mathrm{l}$ well of

Abbreviations: UC, ulcerative colitis; PCR, polymerase chain reaction; TUNEL, terminal uridine DNA nick end labelling; PBS, phosphate buffered saline; CFU, colony forming units; H\&E, haematoxylin and eosin. 
Table 1 Mucosal microflora from patients with ulcerative colitis (UC) and toxicity of mucosal bacteria to Vero cell

\begin{tabular}{|c|c|c|c|}
\hline \multirow[b]{2}{*}{ Organism } & \multicolumn{2}{|c|}{ Inflamed mucosa in UC $(n=10)$} & \multirow[b]{2}{*}{$\begin{array}{l}\text { Cytotoxicity to } \\
\text { vero cell }\end{array}$} \\
\hline & $\begin{array}{l}\text { No of } \\
\text { organisms* }\end{array}$ & $\begin{array}{l}\text { Detection rate } \\
(\%) \dagger\end{array}$ & \\
\hline Enterococcus casseliflavus & 3 & 10 & Negative \\
\hline Enterococcus feacium & $5.40(1.04)$ & 30 & Negative \\
\hline Escherichia coli & $4.77(0.03)$ & 20 & Negative \\
\hline Staphylococcus epidermidis & 4.36 & 10 & Negative \\
\hline Streptococcus sanguis & 5.15 & 10 & Negative \\
\hline Bacteroides distasonis & $4.76(0.90)$ & 50 & Negative \\
\hline Bacteroides fragilis & 8.48 & 10 & Negative \\
\hline Bacteroides ovatus & 4.26 & 10 & Negative \\
\hline Bacteroides uniformis & 4.71 & 10 & Negative \\
\hline Bacteroides vulgatus & $4.71(0.51)$ & 50 & Negative \\
\hline Clostridium clostridioforme & 4.51 & 10 & Negative \\
\hline Clostridium ramosum & 3.97 & 10 & Negative \\
\hline Eubacterium aerofaciens & 5.59 & 10 & Negative \\
\hline Eubacterium lentum & $4.56(0.07)$ & 30 & Negative \\
\hline Fusobacterium varium & $4.75(0.72)$ & 50 & Positive \\
\hline Porphyromonas asaccharolytica & 3.66 & 10 & Negative \\
\hline Prevotella oralis & $4.17(0.31)$ & 30 & Negative \\
\hline Prevotella ruminicola & $4.13(0.23)$ & 30 & Negative \\
\hline Veillonella alcalescens & 4.53 & 10 & Negative \\
\hline Veillonella parvula & $4.22(0.62)$ & 20 & Negative \\
\hline
\end{tabular}

Vero cell cultures that had been grown in 96 well plates. Cultures were incubated at $37^{\circ} \mathrm{C}$ for 96 hours and examined for the proportion of cells with morphological changes. When a supernatant showed toxicity to Vero cells, the twice diluted supernatant with phosphate buffered saline (PBS) was retested for toxicity. Culture supernatant of E coli O157:H7 EDL-931 was used as a positive control, and negative controls were PBS and ABCM broths.

\section{Polymerase chain reaction (PCR)}

Bacteria from one or two colonies of each cytotoxic strain were tested for verotoxin genes, as described elsewhere. ${ }^{19}$ Amplification was with the following primer sets: $5^{\prime}$-AGTTAAT GTGGTGGCGAA-3' and 5'-GACTCTTCCATCTGCCG-3' for verotoxin 1 (from nucleotides 289 to 1,099 ), and $5^{\prime}$ TTCGGTATCCTATTCCCG-3' and 5'-TCTCTGGTCATTGTATTA-3' for verotoxin 2 (289 to 759 ) (Takara Shuzo, Ohtsu, Shiga, Japan). PCR conditions were three minutes at $94^{\circ} \mathrm{C}, 30$ seconds at $55^{\circ} \mathrm{C}$, and 30 seconds at $72^{\circ} \mathrm{C}$ for 25 cycles, and amplified DNA was analysed by submarine gel electrophoresis ( $1.5 \%$ agarose; $5 \mathrm{~V} / \mathrm{cm}$ ) and stained with ethidium bromide. As a positive control, template DNA of $E$ coli O157:H7 EDL-913 was included.

\section{Identification of toxin size}

Culture supernatants of cytotoxic bacteria were concentrated 20 -fold with Centriprep concentrators (molecular weight cut offs 100000 to 3000; Amicon, Beverly, Massachusetts, USA) and with Diaflo ultrafiltration membranes YCl and YC05 (molecular weight cut offs 1000 and 500; Amicon). Dialysates were assayed for toxicity. For inactivation of heat unstable endotoxin, concentrates and dialysates were heated at $120^{\circ} \mathrm{C}$ for 15 minutes. Concentrates and dialysates were tested for protease sensitivity by incubation at $37^{\circ} \mathrm{C}$ for one hour, both with and without a mixture of pronase and trypsin $(200 \mu \mathrm{g} / \mathrm{ml}$ each).

\section{Organic acid assay}

Supernatants of cytotoxic bacteria were assayed for organic acid concentrations. The aqueous phase was filtered through a cellulose acetate membrane (pores $0.20 \mu \mathrm{m}$; DISMIC-13 cp; Tokyo Roshi, Tokyo, Japan) and samples were examined by

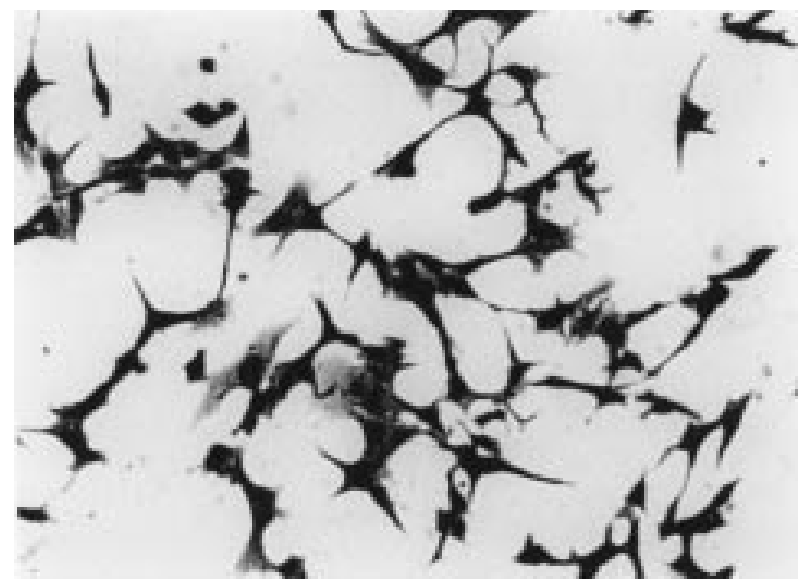

Figure 1 Cytotoxic effects of culture supernatant of one strain of $F$ varium on Vero cells. Cells had long filamentous tendrils, were rounded, and many were detaching into the culture medium. Culture supernatant of $E$ coli O157:H7 EDL-931, which produces verotoxin, had the same effects (not shown). Uninoculated culture broths gave no cytotoxicity.

high performance liquid chromatography, as described elsewhere. ${ }^{20}$ Mean concentrations of organic acids in toxic culture supernatants were determined, and solutions of each organic acid were tested for toxicity. The cytotoxicity of organic acids in toxic culture supernatants was compared in dose-response experiments. The lowest mean concentration that killed $>99 \%$ of cells after 96 hours of incubation was estimated by counting non-adherent cells under a microscope. Untreated Vero cells were used as controls. $\mathrm{pH}$ was measured in both organic acid treated and control wells of Vero cell cultures using a pH meter (PH501 1A, Custom Co., Tokyo, Japan).

\section{In vivo toxicity test}

Four week old male CBA/J mice were given an enema of $32 \mathrm{mmol} / \mathrm{l}$ butyric acid ( $\mathrm{pH} 3.2$ ) under ether inhalation anaesthesia. The concentration was extrapolated from the mean concentration of $n$-butyric acid in separate culture supernatants of all five cytotoxic strains (all Fusobacterium varium) 
Table 2 Concentrations of organic acids in broth with and without Fusobacterium varium isolated from colonic mucosa of patients with ulcerative colitis

\begin{tabular}{|c|c|c|c|c|c|}
\hline \multirow[b]{2}{*}{ Organic acid } & \multicolumn{3}{|c|}{ Mean concentration $(\mathrm{mM})$ in: } & \multirow[b]{2}{*}{$\begin{array}{l}\text { Cytotoxicity to } \\
\text { Vero cell }\end{array}$} & \multirow[b]{2}{*}{$\begin{array}{l}\text { Lowest concentration for } \\
\text { cytotoxicity } \dagger[\mathrm{pH}]\end{array}$} \\
\hline & $\begin{array}{l}\text { Culture } \\
(n=5)\end{array}$ & $\begin{array}{l}\text { ABCM broth only } \\
(n=2)\end{array}$ & $\begin{array}{l}\text { Well of Vero cell culture } \\
{[\mathrm{pH}]}\end{array}$ & & \\
\hline Maleic acid & $0.108(0.011)^{*}$ & 0.188 (0.019) & $0.022[7.87(0.18)]$ & - & $5.0[6.30(0.08)]$ \\
\hline Succinic acid & $7.51 \quad(0.93)$ & $1.04(0.28)^{\prime}$ & $1.50[7.16(0.11)]$ & - & $6.5[5.77(0.08)]$ \\
\hline Lactic acid & $16.3 \quad(5.90)$ & $9.99 \quad(1.23)$ & $3.26[7.27(0.14)]$ & - & $12\left[\begin{array}{lll}6.24 & (0.10)]\end{array}\right]$ \\
\hline Formic acid & 1.17 (0.37) & $1.28 \quad(0.05)$ & $0.234[7.84(0.17)]$ & - & $5.0[7.03(0.10)]$ \\
\hline Acetic acid & $26.5 \quad(3.5)$ & $4.49 \quad(0.22)$ & $5.30[6.93(0.13)]$ & - & $17 \quad\left[\begin{array}{ll}5.02 & (0.09)\end{array}\right]$ \\
\hline Propionic acid & $7.13 \quad(0.56)$ & ND & $1.43[7.52(0.23)]$ & - & $5.0[7.02(0.08)]$ \\
\hline n-Butyric acid & $32.1 \quad(3.9)$ & ND & $6.42[6.90(0.15)]$ & + & $1.5[7.65(0.10)]$ \\
\hline Total & $(4.6)$ & (1.1) & & & \\
\hline
\end{tabular}

* Results are means (SD)

†Fifthfold diluted concentration of organic acids in cultured broth with Fusobacterium varium.

ND, not detected

after incubation for 72 hours at $37^{\circ} \mathrm{C}$. Mice were treated with $1.0 \mathrm{ml}$ of the butyric acid solution $(\mathrm{n}=8)$ or the supernatants (pH 6.3-6.6) from $F$ varium cells grown to a concentration of $1 \times 10^{9}$ colony forming units $(\mathrm{CFU}) / \mathrm{ml}(\mathrm{n}=9)$. Control mice were given an enema of $1.0 \mathrm{ml}$ of $2 \mathrm{mmol} / \mathrm{l} \mathrm{HCl}(\mathrm{n}=8, \mathrm{pH}$ $2.22)$, PBS $(n=10)$, or ABCM broth $(n=8)$. The anal verge was shut with cyanoacrylate and animals were killed under ether anaesthesia 24 hours later. Up to $3 \mathrm{~cm}$ of the rectum and colon from the anal verge were removed and fixed in $10 \%$ buffered formalin ( $\mathrm{pH}$ 7.2). Longitudinal blocks were embedded and stained with haematoxylin and eosin (H\&E). The remaining tissue was frozen in liquid nitrogen and cryostat sections were examined for apoptosis using terminal uridine DNA nick end labelling (TUNEL). ${ }^{21}$ The severity of UC in one longitudinal section from each colorectum was graded histologically on a scale of 0 to 4 and expressed in terms of a pathological index. The modified standard scoring system ${ }^{17}$ was evaluated numerically in a blind fashion, according to the following scheme: 0 , normal; 1 , focal inflammatory cell infiltration including polymorphonuclear leucocytes; 2, gland loss with inflammatory cell infiltration or crypt abscesses; 3 , mucosal ulceration ( $<1 \mathrm{~mm}$ long); and 4, multiple ulcerations or long mucosal ulceration ( $\geqslant 1 \mathrm{~mm}$ long). At least 2500 epithelial cells were counted in each section and the number of affected cells per 100 cells was expressed as the apoptotic index (\%). For each mouse, one pathologist (IO), blind to the results of treatment, made an independent histological diagnosis.

\section{Statistical analysis}

Differences in pathological and apoptotic indices between groups given different enemas were evaluated by the Mann-Whitney U test with Bonferroni's correction. Differences with $\mathrm{p}<0.05$ were considered to be statistically significant.

\section{RESULTS}

\section{In vitro toxicity of mucosal bacteria}

Table 1 lists the isolated bacterial species. All strains detected were susceptible to imipenem and the number of organisms cultured in ABCM broth at $37^{\circ} \mathrm{C}$ for 72 hours was $1-2 \times 10^{9}$ $\mathrm{CFU} / \mathrm{ml}$. Culture supernatants of all five $F$ varium strains were cytotoxic for Vero cells ( fig 1 ). Twice diluted supernatants of all five $F$ varium strains were also cytotoxic for Vero cells but supernatants diluted 1:4 were not cytotoxic. On the other hand, genes coding for verotoxin were not found in $F$ varium.

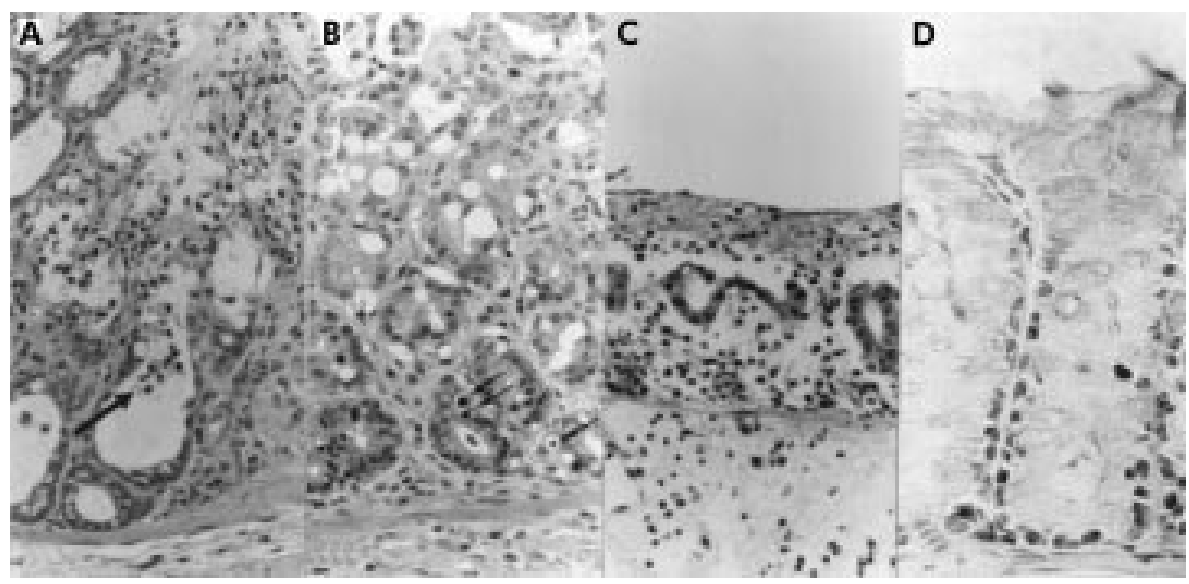

Figure 2 In vivo effects of butyric acid, culture supernatant of $F$ varium, and control substances on colorectal mucosa of mice. (A) Crypt abscess formation in a mouse treated with butyric acid. Inflammatory cell infiltration and early erosive changes are apparent in the upper portion of the colorectal mucosa. A crypt abscess (arrow) is noted. Pathological index of 3 (24 hours after butyrate enema, haematoxylin and eosin $(\mathrm{H} \& \mathrm{E})$, original magnification $\times 400)$. (B) Early mucosal changes in a mouse treated with a culture supernatant of $F$ varium. Degenerative changes are evident in the superficial layer of the colorectal mucosa. Several apoptotic bodies (arrows) are present in the lower portions of the intestinal crypts. Mild inflammatory cell infiltration can be seen in the lamina propria. Pathological index of 2 (24 hours after supernatant enema, H\&E, original magnification $\times 400$ ). (C) Early diffuse erosion in a mouse treated with a culture supernatant of $F$ varium. Diffuse erosive change is apparent in the colorectum, which shows luminal inflammatory exudation. Severe inflammatory cell infiltration can be seen in the lamina propria, with extensive gland loss. Pathological index of 4 (supernatant enema, H\&E, original magnification $\times 400$ ). (D) In this mouse and other mice treated with culture supernatant or butyric acid, many apoptotic cells are evident with terminal uridine DNA nick end labelling (TUNEL) in the lower part of the intestinal crypts (butyric acid enema, original magnification $\times 300$ ) 


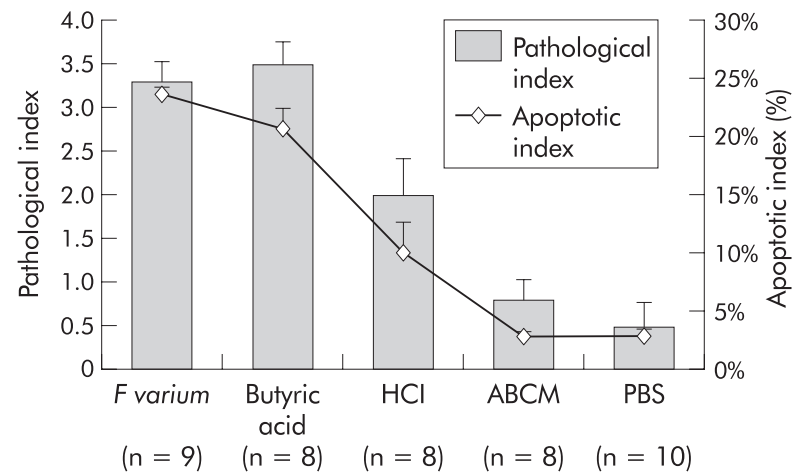

Figure 3 Pathological and apoptotic indices of ulcerative colitis-like lesions caused in the colorectum by $F$ varium culture supernatant or butyric acid enemas. The mean pathological index of mice treated with $F$ varium (3.3) or butyric acid (3.5) was higher than that of mice treated with $\mathrm{HCl}(p=0.021$ and 0.019$), A B C M$ broth (both $\mathrm{p}<0.001)$, or phosphate buffered saline (PBS) (both $\mathrm{p}<0.001)$. Similarly, the mean apoptotic indices for mice treated with $F$ varium $(24.0 \%)$ or butyric acid $(20.8 \%)$ were higher than for $\mathrm{HCl}$ $(p=0.0045$ and 0.012$), A B C M$ broth (both $p<0.001)$, or PBS (both $\mathrm{p}<0.001)$. The mean apoptotic index of mice treated with $\mathrm{HCl}$ $(10.1 \%)$ was higher than that of ABCM broth or PBS (both $\mathrm{p}<0.001)$. Values are mean (SD); statistical analyses were performed using the Mann-Whitney $U$ test with Bonferroni's correction.

Neither the supernatants from other species nor the cultivation broth were toxic (table 1). The culture supernatant of the $E$ coli positive control was toxic.

\section{Identification of verotoxin}

We tried to identify the toxic substance(s) from $F$ varium. Supernatants passaged through a filter with a molecular weight cut off of 500 were treated with both heat and proteases. The treated supernatants remained toxic to Vero cells, suggesting that the toxin was a small non-proteinaceous molecule. Organic acids that are possible toxins and concentrations detected in the supernatants of both $F$ varium and $\mathrm{ABCM}$ broth control are listed in table 2 . The highest mean concentration of an organic acid produced by $F$ varium was that of $n$-butyric acid, at 32.1 (SD 3.9) mmol/l. As $25 \mu \mathrm{l}$ of culture supernatant were added to $100 \mu \mathrm{l}$ of Vero cell cultures, the final concentration of an organic acid in 96 well plates was a 1:5 dilution of the original concentration. The mean concentration of $n$-butyric acid produced a $\mathrm{pH}$ of 3.2 in cell culture supernatants, and pH 6.90 was cytotoxic for Vero cells. pH in cultures with butyric acid was the same as that with acetic acid. However, acetic acid at a mean concentration was not cytotoxic.

With regard to dose-response experiments, comparing the cytotoxicity of organic acids in toxic culture supernatants, the lowest mean concentrations of organic acids and $\mathrm{pH}$ values at which $>99 \%$ of cells were killed is shown in table 2 . As concentrations of organic acids, except for $n$-butyric acid, in Vero cell culture were less than the lowest mean concentrations that produced cytotoxicity, concentrations of organic acids other than $n$-butyric found in the culture supernatants were not considered to be toxic.

\section{Experimental UC-like colonic ulcers}

Visual inspection showed mucosal erosions in the colorectum of mice treated with supernatants of $F$ varium or butyric acid. Both mucosal erosions and infiltration by inflammatory cells, including neutrophils, were observed microscopically. Mice treated with supernatants of $F$ varium or butyric acid had more apoptotic bodies in mucosa than controls (fig 2). The pathological indices for such mice (fig $3 ; F$ varium, median 3 (interquartile range 3,4$)$; butyric acid $4(3,4) ; \mathrm{p}=0.973$ ) were higher than those for control mice $(\operatorname{HCl} 2(1.5,2.5), \mathrm{p}=0.073$; ABCM broth $1(0,1), p=0.002$; and PBS $0(0,1), p=0.001)$. Similarly, apoptotic indices were elevated ( $F$ varium, median $23.2 \%$ (interquartile range 20.2, 24.6); butyric acid $21.4 \%$ $(19.3,23.0) ; \mathrm{p}=0.776)$ compared with controls ( $\mathrm{HCl} 8.3 \%$ (6.6, $10.5), \mathrm{p}=0.021$; $\mathrm{ABCM}$ broth $2.9 \%(2.7,3.2), \mathrm{p}=0.002$; and PBS $2.4 \%(2.1,5.3), \mathrm{p}<0.001)$.

\section{DISCUSSION}

Our data suggest that the main toxin from culture supernatants of $F$ varium is butyric acid. We found no evidence to support the identification of the toxic substance produced by $F$ varium as verotoxin. Verotoxin, originally found to be produced by an enterohaemorrhagic $E$ coli strain, ${ }^{18}$ has a molecular weight of 70000 . The verotoxin gene is readily detectable by PCR. ${ }^{19}$ Our efforts to detect the verotoxin gene, using appropriate PCR technology, indicated that it was not present. The toxicity of our butyric acid containing supernatants was consistent with reports of in vitro toxicity of butyric and propionic acids from dental plaque, ${ }^{22}$ and butyric acid in culture filtrates of two Bacteroides species. ${ }^{23}{ }^{24}$ As the mean concentration of butyric acid produced culture conditions of $\mathrm{pH} 3.20$ in the supernatants, but the $\mathrm{pH}$ changed to $\mathrm{pH} 6.90$ in wells that were cytotoxic for Vero cells, cytotoxicity does not appear to be related to $\mathrm{pH}$.

Acetic acid, propionic acid, and butyric acid are produced by anaerobic bacteria in the colon ${ }^{25}$ and are rapidly absorbed to provide energy for the colorectal epithelium. ${ }^{26}$ However, butyrate, ${ }^{27}{ }^{28}$ propionate, and acetate also induce apoptosis in a number of colorectal tumour cell lines. Butyrate has the greatest effect. ${ }^{29}$ Therefore, toxicity towards Vero cells may involve induction of apoptosis by butyric acid produced by bacteria. The higher apoptotic indices in mice treated with butyric acid or supernatants of cultured $F$ varium, compared with controls, is in agreement with results in patients with active UC..$^{30}$

Our data do not support the possibility that increased luminal acidity causes epithelial damage in our model. Specifically, mucosal erosions were observed in mice treated with $\mathrm{pH}$ 6.36.6 supernatants of $F$ varium but not in control mice treated with $\mathrm{HCl}$ ( $\mathrm{pH} 2.22$ ). Our results showed that apoptotic indices in the mucosa treated with $F$ varium and butyric acid were elevated compared with controls treated with $\mathrm{HCl}$, ABCM broth, or PBS. Therefore, it is more likely that butyric acid and butyric acid rich supernatants of cultured $F$ varium in the enemas induced mucosal cell apoptosis that caused the ulceration, rather than acidity.

Defective butyrate metabolism may be involved in the pathogenesis of UC. Colonocytes from patients with UC oxidise less butyric acid than cells from controls without mucosal abnormalities. ${ }^{32}$ It is possible that the high concentrations of butyric acid and butyric acid rich supernatants of cultured $F$ varium in the enemas administered to mice were in excess of that which could be metabolised by the colonic epithelium, thus inducing mucosal cell apoptosis and causing ulceration. Our finding that butyric acid is associated with ulceration is seemingly in contradiction to reports that enemas of sodium butyrate have been used successfully to treat UC. ${ }^{33}$ However, in a controlled trial, enemas of sodium butyrate were not effective in the treatment of $\mathrm{UC}^{34}$ and the substance used in the reported studies is not the same as the butyric acid that was used in our experiments.

Our immunochemical analysis of biopsy specimens from active UC cases suggests that $F$ varium invades the mucus and mucosa and lives in crypts. ${ }^{35}$ Production of butyric acid within these crypts would be expected to impact directly on epithelial cells. Similarly, H pylori can be found in the gastric mucosa of most patients with chronic gastritis or peptic ulcers, ${ }^{36}$ inhabiting the mucous layer of the epithelium or invading the epithelium itself. ${ }^{37} 38$ 


\section{ACKNOWLEDGEMENTS}

We thank Dr K Ariake and Mr Y Ozaki for technical assistance in toxicity testing, and Dr T Yokoyama (Department of Epidemiology, Medical Research Institute, Tokyo Medical and Dental University) for statistical analyses.

\section{Authors' affiliations}

T Ohkusa, T Ogihara, N Sato, Department of Gastroenterology, Juntendo University, School of Medicine, Tokyo, Japan

I Okayasu, Department of Pathology, School of Medicine, Kitasato University, Sagamihara, Japan

K Morita, Department of Microbiology, School of Health Sciences, Kyorin University, Hachioji, Japan

M Ogawa, Kawasaki City Institute for Public Health, Kawasaki, Japan

\section{REFERENCES}

1 Rubin PH, Present DH. Differential diagnosis of chronic ulcerative colitis and Crohn's disease of the colon: one, two, or many diseases? In: Kirsner JB, Shorter RG, eds. Inflammatory bowel disease, 4th Edn. Baltimore: Williams and Wilkins, 1995:355-79.

2 Panwala CM, Jones JC, Viney JL. A novel model of inflammatory bowel disease: mice deficient for the multiple drug resistance gene, $\mathrm{mdrla}$ spontaneously develop colitis. J Immunol 1998;161:5733-44.

3 Sadlack B, Merz H, Schorle H, et al. Ulcerative colitis-like disease in mice with a disrupted interleukin-2 gene. Cell 1993;75:253-61.

4 Sellon RK, Tonkonogy S, Schultz M, et al. Resident enteric flora are necessary for development of spontaneous colitis and immune system activation in IL-10- deficient mice. Infect Immun 1998;66:5224-31.

5 Dianda L, Hanby AM, Wright NA, et al. T cell receptor- $\alpha \beta$-deficient mice fail to develop colitis in the absence of a microbial environment. Am J Pathol 1997;150:91-7

6 van der Wiel-Korstanje JAA, Winkler KC. The faecal flora in ulcerative colitis. J Med Microbiol 1975;8:491-501.

7 Burke DA, Axon ATR. Adhesive Escherichia coli in inflammatory bowe disease and infective diarrhoea. BMV 1988:297:102-7.

8 von Wulffen $\mathbf{H}$, Russman $\mathrm{H}$, Karch $\mathrm{H}$. Verocytotoxin-producing Escherichia coli O2: $\mathrm{H} 5$ isolated from patients with ulcerative colitis. Lancet 1989;i: 1449-50

9 Olusanya O, Steinruck H, Aleliung P, et al. Surface properties, connective tissue protein binding and Shiga-like toxin production of Escherichia coli isolated from patients with ulcerative colitis. Int J Med Microbiol 1992;276:254-63.

10 Giaffer MH, Holdsworth CD, Duerden BI. Virulence properties of Escherichia coli strains isolated from patients with inflammatory bowel disease. Gut 1992:33:646-50.

11 Mann BJ, Petri WA Jr. The role of microbial adherence factors in gastrointestinal disease. In: Blaser M, Smith PD, Ravdin Jl, et al, eds. Infections of the gastrointestinal tract. New York: Raven Press, 1995:99-105.

12 Ohkusa T, Okayasu I, Tokoi S, et al. Bacterial invasion into the colonic mucosa in ulcerative colitis. J Gastroenterol Hepatol 1993;8:1 16-18.

13 Swidsinski A, Ladhoff A, Pernthaler A, et al. Mucosal flora in inflammatory bowel disease. Gastroenterology 2002;22:44-54.

14 Donnenberg M. Cellular invasion by bacteria: lessons from in vitro models. Gastroenterology 1994;107:1193-203.

15 Drusano GL, Standiford HC. Pharmacokinetic profile of imipenem/cilastatin in normal volunteers. Am J Med 1985;78/supp 6A):47-53.

16 Kesado T, Watanabe K, Asahi Y, et al. Susceptibilities of anaerobic bacteria to $\mathrm{N}$-formimidoyl thienamycin (MK0787) and to other antibiotics. Antimicrob Agents Chemother 1982;21:1016-22.
17 Okayasu I, Hatakeyama S, Yamada $M$, et al. A novel method in the induction of reliable experimental acute and chronic ulcerative colitis in mice. Gastroenterology 1990;98:694-702.

18 Konowalchuk J, Speirs JI, Stavric S. Vero response to a cytotoxin of Escherichia coli. Infect Immun 1977; 18:775-9.

19 Jackson MP, Newland JW, Holmes RK, et al. Nucleotide sequence analysis and comparison of the structural genes for Shiga-like toxin I and Shiga-like toxin II encoded by bacteriophages from Escherichia coli 933. FEMS Microbiol Lett 1987:44:109-14.

20 Hoshi S, Sakata T, Mikuni K, et al. Galactosylsucrose and xylosylfructoside alter digestive tract size and concentrations of cecal organic acids in rats fed diets containing cholesterol and cholic acid. $J$ Nutr 1994;124:52-60.

21 Gavrieli Y, Sherman Y, Ben-Sasson SA. Identification of programmed cell death via specific labeling of nuclear DNA fragmentation. J Cell Biol 1992;119:493-501.

22 Singer RE, Buckner BA. Butyrate and propionate: important components of toxic dental plaque extracts. Infect Immun 1981;32:458-63.

23 Touw JJA, van Steenbergen TJM, de Graaff J. Butyrate: a cytotoxin for Vero cells produced by Bacteroides gingivalis and Bacteroides asaccharolyticus. Antonie van Leeuwenhoek 1982:48:315-25.

24 van Steenbergen TJM, den Ouden MD, Touw JJA, et al. Cytotoxic activity of Bacteroides gingivalis and Bacteroides asaccharolyticus. J Med Microbiol 1982;5:253-8.

25 Cummings JH, Pomare EW, Branch WJ, et al. Short chain fatty acids in human large intestine, portal, hepatic and venous blood. Gut 1987;28: 1221-7

26 Scheppach W. Effects of short chain fatty acids on gut morphology and function. Gut 1994;35(suppl 1):S35-8.

27 Hague A, Manning AM, Hanlon KA, et al. Sodium butyrate induces apoptosis in human colonic tumour cell lines in a p53-independent pathway: implications for the possible role of dietary fibre in the prevention of large-bowel cancer. Int J Cancer 1993;55:498-505.

28 Heerdt BG, Houston MA, Augenlicht LH. Potentiation by specific short-chain fatty acids of differentiation and apoptosis in human colonic carcinoma cell lines. Cancer Res 1994;54:3288-94.

29 Hague A, Elder DJE, Hicks DJ, et al. Apoptosis in colorectal tumour cells: induction by the short chain fatty acids butyrate, propionate and acetate and by the bile salt deoxycholate. Int J Cancer 1995;60:400-6.

30 Strater J, Wellisch I, Riedl S, et al. CD95 (APO-1/Fas)-mediated apoptosis in colon epithelial cells: a possible role in ulcerative colitis. Gastroenterology 1997;113:160-7.

31 Arai N, Mitomi H, Ohtani Y, et al. Enhanced epithelial cell turnover associated with p53 accumulation and high p2 $1^{\text {WAF1/CIP1 }}$ expression in ulcerative colitis. Mod Pathol 1999;12:604-11

32 Roedinger WEW. The colonic epithelium in ulcerative colitis: an energy-deficiency disease. Lancet 1980;ii:712-15.

33 Scheppach W, Sommer H, Kirchner T, et al. Effect of butyrate enemas on the colonic mucosa in distal ulcerative colitis. Gastroenterology 1992:103:51-6.

34 Steinhart AH, Hiruki T, Brzezinski A, et al. Treatment of left-sided ulcerative colitis with butyrate enemas: a controlled trial. Aliment Pharmacol Ther 1996:10:729-36.

35 Ohkusa T, Sato N, Ogihara T, et al. Fusobacterium varium localized in the colonic mucosa of patients with ulcerative colitis stimulates species-specific antibody. J Gastroenterol Hepatol 2002; 17:849-53.

36 Marshall BJ, Warren JR. Unidentified curved bacilli in the stomach of patients with gastritis and peptic ulceration. Lancet 1984;i:1311-14.

37 Marshall BJ, Armstrong JA, McGechie DB, et al. Attempt to fulfill Koch's postulates for pyloric campylobacter. Med J Aust 1985;142:436-9.

38 Chen XG, Correa P, Offerhaus J, et al. Ultrastructure of the gastric mucosa harboring Campylobacter-like organisms. Am J Clin Pathol 1986;86:575-82. 